ISSN1027-5495. Functional Materials, 25, No.1 (2018), p. 122-127

\title{
Fragmentation fractal of sandstone under acid corrosion and coupled static-dynamic loads
}

\author{
LIU Yong-sheng, LI Jin, ZOU Jia-yu, WU Yun, LU Shao-yong \\ School of Civil Engineering and Architecture, East China Jiaotong \\ University, Nanchang 330013, P.R.China;
}

Received November 30, 2017

\begin{abstract}
The analysis results show that the fragment of broken rock is a fractal distribution, and the smaller the impact pressure is, the less specimen fragments is, the lower degree of fragmentation degree is, and the lower fractal dimension is. Research shows that fractal dimension increases with the dynamic compression strength of rock increasing, and the incident energy and the absorb energy increase linear with the fracture fractal dimension increasing. The fragmentation distribution of the specimens becomes more and more uniform with the increasing of the incident energy, and the characteristic scale of rupture decreased gradually.

Key words: rock dynamics; fragmentation fractal; acid corrosion; coupled static-dynamic loads; strength; energy.

Обсуждается взаимосвязь между фрактальной размерностью и динамической прочностью на сжатие, диссипацией энергии в породе под кислотной коррозией и связанными статически-динамическими нагрузками. Результаты анализа показывают, что фрагменты разрушенной породы имеют фрактальное распределение, и чем меньше ударное давление, тем меньше фрагментов, меньше степень фрагментации и меньше фрактальная размерность. Исследования показывают, что фрактальная размерность возрастает с ростом динамической прочности породы на сжатие. Фрактальная размерность линейно возрастает с вложенной энергией и поглощённой энергией. Распределение фррагментов образцов становится все более однородным с ростом вложенной энергии, а характерный их масштаб постепенно уменьшается.

Фрагментаційний фрактал пісковика під кислотною корозією та пов'язані статично-динамічні навантаження. LIU Yong-sheng, LI Jin, ZOU Jia-yu, WU Yun, LU Shao-yong.

Обговорюеться взаємозв'язок між фррактальної розмірністю і динамічною міцністю на стиск, дисипацією енергії в породі під кислотної корозією і пов'язаними статичнодинамічними навантаженнями. Результати аналізу показують, що фрагменти зруйнованої породи мають фрактальний розподіл, і чим менше ударний тиск, тим менше фрагментів, менше ступінь фрагментації і менше фрактальна розмірність. Дослідження показують, що фррактальна розмірність зростае з ростом динамічної міцності породи на стиск. Фрактальна розмірність лінійно зростае з вкладеною енергією і поглиненої енергією. Розподіл фррагментів зразків стає все більш однорідним з ростом вкладеної енергії, а характерний їх масштаб поступово зменшуеться.
\end{abstract}




\section{Introduction}

Rock is a kind of heterogeneous brittle media. the internal micro cracks will be develop and expand continuously under the influence of the deep complex environment and the high ground stress. The degree of difficulty, energy consumption and fragmentation distribution of rock fragmentation are important parameters and measure index in rock drilling, blasting, mining and mineral processing. With the development of fractal theory in the 70 s of last century, the study of rock fracture has entered a new stage. A large number of studies [1-3] showed that the development of the rock fragment from microscopic damage to the macroscopic crack has fractal characteristics, and the fragment is fractal distribution.

In recent years, fractal theory has been widely used in the field of rock fragmentation and energy analysis, and a lot of research results have been obtained. Xu Jin-yu et al. [7] analyzed the fragmentation lumpiness distribution of marble under impact loading test by fractal geometry. Nagahama[8] studied the process of the damage and energy dissipation of rock by fractal theory. Wang Qi-sheng et al.[9] studied the fragmentation fractal characteristics of granite under the static and dynamic coupled loads, and analyzed the change of rock fragmentation fractal dimension with different loads.

In previous studies, they all did not take into account the effects of deep underground environment. In fact, the influence of deep underground complex environment on the rock properties can not be ignored in engineering practice, and most of the deep rock are in acidic environment of underground water. In addition, the deep rock is in a the coupled of static and dynamic stress state. So there are great practical significance to study the fractal of deep rock considering comprehensively the influence of deep underground environment. In this paper, the fragmentation fractal characteristics of red sandstone under the coupled staticdynamic loads are comprehensively considered, and relationship of the fractal dimension and absorbed energy and dynamic strength were analyzed.

\section{Calculate of fractal dimension}

In the early 70 s of last century, French scientist B. B. Mandelbrot put forward the concept of fractal theory for the first time. The fractal dimension can be used to describe the features of a graph or object with fractal features[11]. The fragmentation process of rock is very complex, which is the result of the interaction of the external loading and the internal cracks in the rock mass. Based on large numbers of theo- retical and experimental studies, experts and scholars [12-13]had put forward a statistical model of rock fragmentation distribution, and the most representative distribution function are R-R and G-G-S .

The expression of $\mathrm{R}-\mathrm{R}$ distribution:

$$
y=1-\exp \left[-\left(\frac{r}{r_{0}}\right)^{a}\right]
$$

Here $\mathrm{a}$ is the distribution parameter of rock fragments, $r_{0}$ is the characteristic size of the rock fragments, which is the size of the block when the cumulative amount of the sieve is $\left(1-1 / e_{0}\right) \%$.

The expression of G-G-S distribution:

$$
y=\left(\frac{r}{r_{m}}\right)^{b}
$$

Here $b$ is the distribution parameter of rock fragment, which is the linear slope in log-log coordinate. $r_{m}$ is the distribution function. When $r$ $=\mathrm{rm}$, the quantity under sieve is $100 \%$, which is the maximum size of the rock fragments.

Expanding the formula (1) in series and removing of the higher order terms, then we can find that the final results of the formula (1) and formula (2) are the same. In the G-G-S distribution function, the $\mathrm{M}$ represents the total mass of the fragments, the cumulative mass under the sieve is $m(r)$ when the feature size is $r$. And the formula (2) can be converted into:

$$
\frac{m(r)}{M}=\left(\frac{r}{r_{m}}\right)^{b}
$$

Derivative the formula (3):

$$
d m \propto r^{b-1} d r
$$

Considering the relationship between the increment of rock fragments and the mass growth:

$$
d m \propto r^{3} d N
$$

Based on the results of Turcotte et al.[14] the relationship of the fractal dimension $\mathrm{D}$ and the number of fragments $\mathrm{N}$ which is larger than current size and the linear characteristic size $r$ can be show as:

$$
N \propto r^{-D}
$$

Combining formula (4) and (5), the calculation formula of fractal dimension $\mathrm{D}$ can be deduced:

$$
W_{I}(t)=\frac{A_{e} C_{e}}{E_{e}} \int_{0}^{t} \sigma_{I}^{2}(t) d t
$$


Table 1 The loading scheme

\begin{tabular}{|c|c|c|c|c|c|c|}
\hline Loading scheme & \multicolumn{4}{|c|}{ Impact pressure (MPa) } & $\begin{array}{c}\text { Axial static pressure } \\
(\mathrm{MPa})\end{array}$ \\
\hline $\begin{array}{c}\text { Combined static and } \\
\text { dynamic loading }\end{array}$ & 0.45 & 0.50 & 0.55 & 0.60 & 0.65 & 8 \\
\hline
\end{tabular}

In the formula

$$
W_{R}(t)=\frac{A_{e} C_{e}}{E_{e}} \int_{0}^{t} \sigma_{R}^{2}(t) d t
$$

is the total mass,

$$
W_{T}(t)=\frac{A_{e} C_{e}}{E_{e}} \int_{0}^{t} \sigma_{T}^{2}(t) d t
$$

is the cumulative quality of the all fragment which diameter is less than $R$.

According to the formula (7), the fractal dimension D can be calculated from the cumulative mass under sieve of the different particle size.

\section{Experimental scheme and results}

The experiment is carried out on the basis of the coupled static-dynamic loading testing system as shown in Figure 1. The loading scheme is shown as Table 1 .

Red sandstone was chosen as the research object. The specimen size is cylinders with $50 \mathrm{~mm}$ in diameter and $25 \mathrm{~mm}$ high. In order to simulate the acidic environment of deep underground, the acid solution with $\mathrm{pH}=4$ were prepared according to the characteristics of the deep water, and the specimen are immersed in the acid solution for 30 days.

After the experiment of coupled static-dynamic loads. All the broken fragments of rock under different impact pressure were collected by the self-made simple recovery device, and the fragments of rock specimen were sieved according to the relevant national standards. The square hole sieves based on new standard were used to sieve the rock fragments, which hole diameter are $2.5 \mathrm{~mm}, 5 \mathrm{~mm}, 10 \mathrm{~mm}, 16 \mathrm{~mm}$, $20 \mathrm{~mm}, 25 \mathrm{~mm}, 31.5 \mathrm{~mm}, 40 \mathrm{~mm}$ and $50 \mathrm{~mm}$. After screening, the residue quantity under the sieve is weighed by electronic balance each times.

The stress and strain curves of the specimens are obtained as shown Figure 2.

According to [15], the incident energy and absorbed energy of the specimens can be calculated by the formula.

$$
\begin{aligned}
& W_{I}(t)=\frac{A_{e} C_{e}}{E_{e}} \int_{0}^{t} \sigma_{I}^{2}(t) d t \\
& W_{R}(t)=\frac{A_{e} C_{e}}{E_{e}} \int_{0}^{t} \sigma_{R}^{2}(t) d t
\end{aligned}
$$

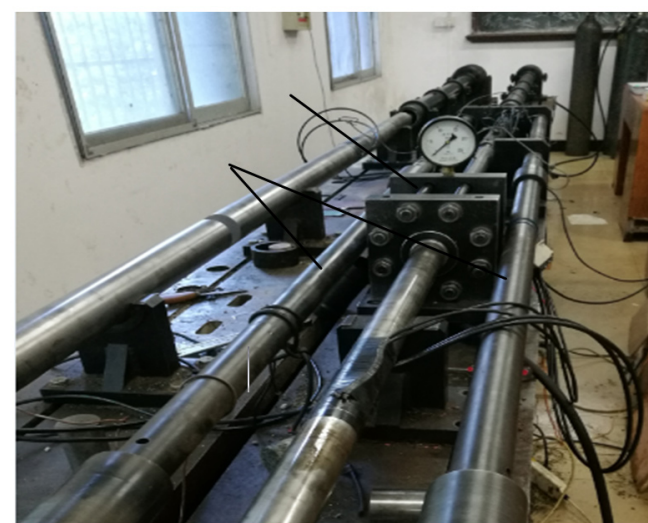

Fig. 1 Coupled static-dynamic loading device

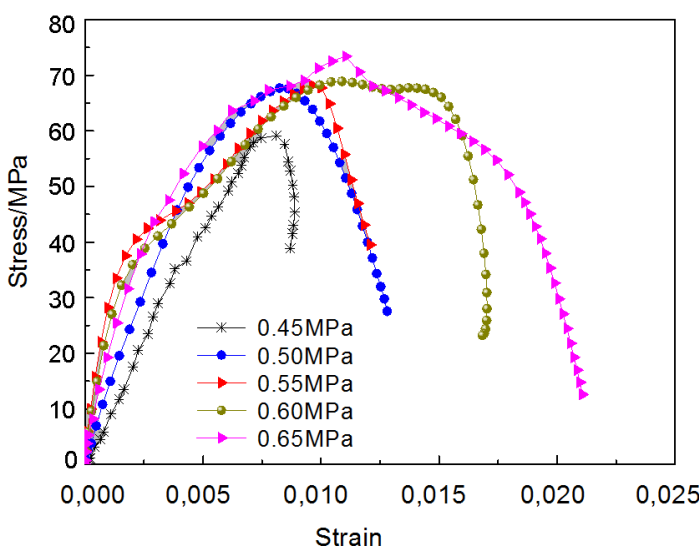

Fig. 2. The stress-strain curves of specimens

$$
W_{T}(t)=\frac{A_{e} C_{e}}{E_{e}} \int_{0}^{t} \sigma_{T}^{2}(t) d t
$$

where $W_{I}(\mathrm{t}), W_{R}(t)$ and $W_{T}(t)$ respectively represent the incident, reflection and transmission energy; $A_{0}$ is the cross-sectional area of elastic rod; $C_{0}$ is the elastic rod wave velocity; $E_{0}$ is the elastic modulus of specimen; $\sigma_{I}(t)$, $\sigma_{R}(t)$ and $\sigma_{T}(t)$ are the incident, reflection and transmission stresses.

The energy absorbed $W_{\mathrm{s}}$ under coupled static-dynamic loads can be showed as:

$$
W_{S}=W_{I}+W_{o}-\left(W_{R}+W_{T}\right.
$$

Where $W_{O}$ is the energy of static loads pressure,

$$
W_{\mathrm{o}}=\int_{0}^{\varepsilon} \sigma(t) d \varepsilon(t)
$$


Table 2 Energy at different impact pressure

\begin{tabular}{|c|c|c|c|c|c|}
\hline Impact pressure (MPa) & 0.45 & 0.50 & 0.55 & 0.60 & 0.65 \\
\hline Dynamic compressive strength(MPa) & 59.14 & 67.72 & 68.21 & 68.91 & 73.42 \\
\hline Incident energy (J) & 44.44 & 67.84 & 76.88 & 90.53 & 105.41 \\
\hline Absorbed energy (J) & 20.11 & 36.32 & 34.35 & 45.88 & 54.70 \\
\hline
\end{tabular}

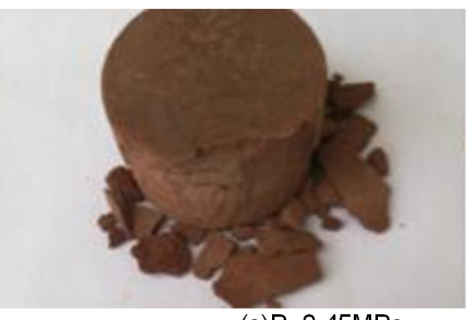

(a) $\mathrm{P}=0.45 \mathrm{MPa}$

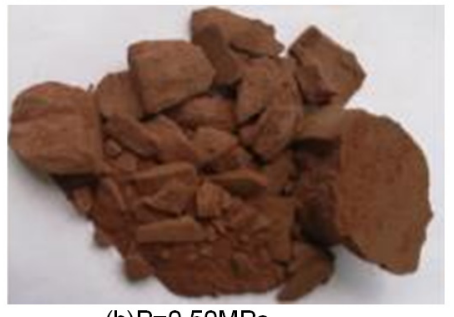

(b) $\mathrm{P}=0.50 \mathrm{MPa}$

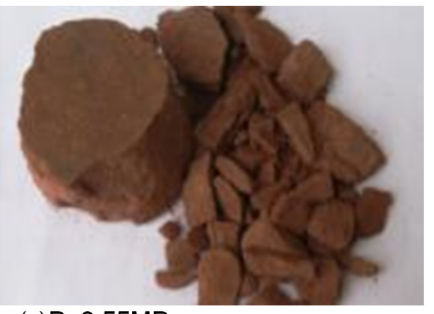

(c) $\mathrm{P}=0.55 \mathrm{MPa}$

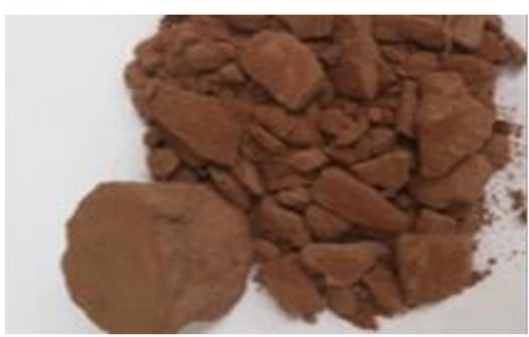

(d) $\mathrm{P}=0.60 \mathrm{MPa}$

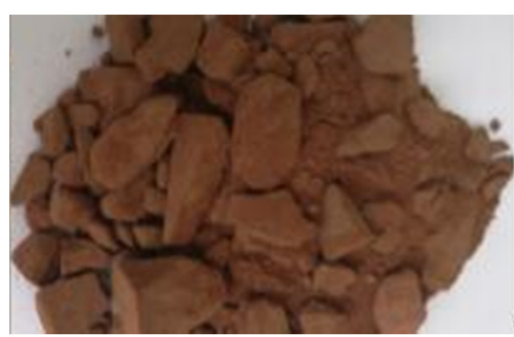

(e) $\mathrm{P}=0.65 \mathrm{MPa}$

Fig. 3. Fragmentation mode of the rock

the incident energy and absorbed energy of the specimens can be calculated as showed Table 2.

The fragmentation mode of rock under acid corrosion and coupled static-dynamic loading are shown in Figure 3, and they were screened by the above experimental scheme, the sieving results is shown in Table 3.

\section{Analysis of fragmentation fractal}

According to the results of the screening experiment, the fractal dimension of the red sandstone under acid corrosion and coupled static- dynamic loads can be calculated by the formula (7), and the results are shown in Table 4.

From Table 4, we knew that the fractal dimension of the specimen with 0.45 impact pressure is smallest in Table 4, and the fractal dimension increased with the impact pressure increasing. This show the fragmentation degree of the specimen with 0.45 impact pressure is lowest, and it rise with impact pressure increasing, which is in agreement with the experimental results form the Figure 2. Through the comparison of the broken mode and fractal dimension, it was found that the fewer the

Table 3 Results of screening experiment

\begin{tabular}{|c|c|c|c|c|c|c|c|c|c|c|}
\hline \multirow{2}{*}{\multicolumn{2}{|c|}{ Residual mass (g) }} & \multicolumn{9}{|c|}{ Hole diameter of sand sieve $(\mathrm{mm})$} \\
\hline & & 2.5 & 5.0 & 10 & 16 & 20 & 25 & 31.5 & 40 & 50 \\
\hline \multirow{5}{*}{$\begin{array}{c}\text { Impact } \\
\text { pressure } \\
(\mathrm{MPa})\end{array}$} & 0.45 & 0.6 & 1.4 & 4.3 & 2.5 & 0 & 0 & 0 & 0 & 99.2 \\
\hline & 0.50 & 7.2 & 3.6 & 14.1 & 15.3 & 11.9 & 0 & 0 & 54.9 & 0 \\
\hline & 0.55 & 3.8 & 2.9 & 11.7 & 14.6 & 4.2 & 0 & 0 & 71.8 & 0 \\
\hline & 0.60 & 17.6 & 8.9 & 23 & 16.4 & 0 & 0 & 40.1 & 0 & 0 \\
\hline & 0.65 & 22.7 & 12.9 & 29.2 & 41.2 & 0 & 0 & 0 & 0 & 0 \\
\hline
\end{tabular}




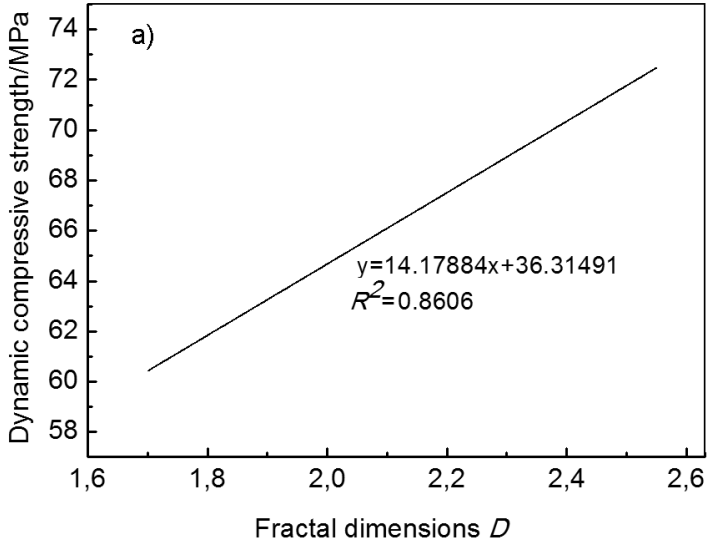

Fig. 4. Relation between dynamic compression strength and fractal dimensions

Table 4 Fractal dimension of different specimens

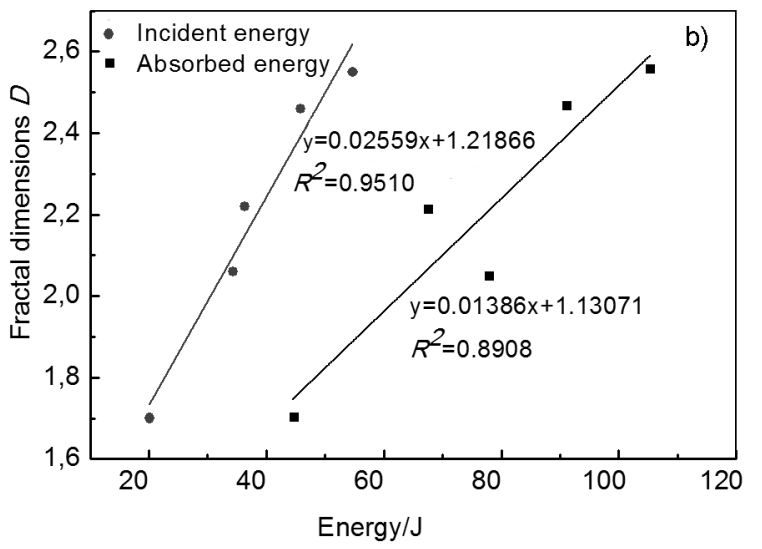

Fig. 5. Relation between energy andfractal dimensions

\begin{tabular}{|c|c|c|c|}
\hline Impact pressure $(\mathrm{MPa})$ & Slope & Fractal dimension & Correlation coefficent \\
\hline 0.45 & 1.303 & 1.70 & 0.8402 \\
\hline 0.50 & 0.781 & 2.22 & 0.9428 \\
\hline 0.55 & 0.936 & 2.06 & 0.9332 \\
\hline 0.60 & 0.542 & 2.46 & 0.9125 \\
\hline 0.65 & 0.449 & 2.55 & 0.9787 \\
\hline
\end{tabular}

sample fragments are, the larger the volume is, the lower the fragmentation degree is, then the lower the fractal dimension is. The fractal dimension of the fragment size distribution can be used to reflect the fragmentation degree of material quantitatively. which shows that the fragmentation distribution of rock specimen has good self-similarity, that is a fractal distribution.

The fractal is not only related to the macroscopic damage of the material, but also to its micro-structure and mechanical properties. According to the results the dynamic test, The changing law of the fractal dimensions and dynamic compression strength and energy of the rock are shown in Figure 4 and Figure 5.

It can be seen from Figure 4 that the dynamic compression strength of rock increases linear with the fractal dimension increasing. The dynamic compression strength rise when the impact pressure increasing, then the crack will develop more fully, and the fragments become more, so the fractal dimension increase. Therefore, the fractal dimension can be used to quantitatively describe the dynamic strength of the specimens. From Figure 5 we can found that the fractal dimension of the acid red sandstone shows a significant upward trend with the increasing of the incident energy under the action of static and dynamic combination. Those results are consistent with the other research results on the fractal dimension of rock subjected to impact dynamic load $[11,13]$. The fragment size distribution of rock sample become more and more uniform with the incident energy increasing, and the characteristic scale of fragment decreases accordingly. The destruction of rock is closely related to the development, expansion and penetration of the internal micro-crack. It is also the process of the development of the initial meso-damage in the rock structure to the macroscopic fracture. The more energy is absorbed, the more the crack expands, and the more the fragment is produced, the higher the degree of fragmentation is, and the fractal dimension is bigger.

\section{Conclusions}

The fractal characteristics of the rock fragmentation under coupling effect of acid corrosion and static-dynamic loading are analyzed in this paper, the results show that:

Research showed that the fractal theory can be applied to analyze the rock properties under acidic environment and coupled loads. There is a close relationship between the fractal di- 
mension, strength of rock, absorbed energy and fragment shape. The fragment size distribution of rock specimens under acid corrosion and coupled static-dynamic loads have good self-similarity, which is the characteristics of fractal distribution. The study on the fractal of rock under acid corrosion and coupled staticdynamic loads can provide reference for the safe mining of deep coal seam.

Experiment results showed that the lower the impact pressure is, the fewer the sample fragments are, the larger the volume of the fragment are, the lower the fragmentation degree is, and the lower the fractal dimension is. The fractal dimension of the fragment can be used to quantitatively described the fragmentation degree of the material.

The fractal dimension increases with the increasing of the incident energy and absorbed energy of the specimens, and the dynamic compression strength of rock samples increases with the increasing of fractal dimension. The fractal dimension can be used to analyze the strength, energy and other internal performance, to explore the inherent law of material failure process.

\section{Acknowledgments}

This work is supported by the Natural Science Foundation of China (51664014, 51274101) and Science and technology project of Jiangxi Provincial Department of Education (GJJ160474).

\section{References}

1. Xie He-ping, Gao Feng. Chinese J. Rock Mech. Eng., 10, 55, 1991.

2. GAO Feng, XIE He-ping, WU Jing-bo. Chinese J. Rock Mech. Eng.,18, 503, 1999.

3. Turcotte D L. J. Geophys., 91,1291, 1988.

7. XU Jin-yu, LIU Shi. Rock Soil Mech., 33, 3225, 2012.

8. Nagahama H. Earth Scie. Front., 7,169, 2000.

9. Wang Qi-sheng, LI Xi-bing. J. Exp. Mech., 24, 587, 2009.

10. TAN Yun-liang, LIU Chuan-xiao, ZHAO Tong-bin. Elementary Theory for Rock Nonliner Dynamics [M]. Beijing: China Coal Industry Publishing House, 2008.

11. Xie He-ping. An Introdction of Fractal Methods on Rock Mechanics. Beijing: Science Press, 1996.

12. Turcotte D L., Tectonophys.,132, 261, 1986.

13. Xie He-ping, Gao Feng, Zhou Hong-wei, et al. J.Seismology, 23, 1, 2003.

14. Guo Lianjun, Yang Yuehui, Zhang Daning. Metal mine, $8,1,2014$

15. Li shi bing Study on rock-breaking rule in deep wells and rock-breaking fractal mechanism daqing petroleum institute Doctoral Dissertation 2006.03 